\title{
Kesulitan Memahami Konsep Kimia Unsur Golongan VII A (Halogen) Pada Mahasiswa Program Studi Pendidikan Kimia Universitas Palangka Raya Tahun Akademik 2018/2019
}

\author{
Farida Meliana Lumban Tobing, Suandi Sidauruk, Ruli Meiliawati
}

Program Studi Pendidikan Kimia, FKIP, Universitas Palangka Raya, Indonesia

\begin{abstract}
Abstrak :Konsep kimia unsur golongan VII A (halogen) merupakan pokok bahasan di Universitas pada mata kuliah kimia dasar. Penelitian ini bertujuan untuk mendeskripsikan kesulitan mahasiswa dalam memahami konsep kimia unsur golongan VII A (halogen) pada Mahasiswa Program Studi Pendidikan Kimia Universitas Palangka Raya tahun akademik 2018/2019. Subjek penelitian yaitu 111 mahasiswa Program Studi Pendidikan Kimia Universitas Palangka Raya. Pengambilan data dilakukan dalam satu kali pertemuan pada tiap semester yang berbeda. Data dijaring menggunakan instrumen wacana kimia unsur halogen (WKUH) dan wawancara. Data yang diperoleh dianalisis secara deskriptif. Hasil penelitian menunjukkan bahwa sebagian besar mahasiswa mengalami kesulitan dalam memahami konsep kimia unsur golongan VII A (halogen). Rerata persentase kesulitan mahasiswa dalam memahami konsep mengidentifikasi sifat kereaktifan, sifat keperiodikan, sifat kelarutan, sifat oksidator dan reduktor, sifat asam-basa, dan mendeskripsikan cara pembuatan, manfaat, dan bahaya unsur golongan VII A (halogen) sebesar 61,94\%, 48,38\%, 64,19\%, 60\%. 68,32\%, $52,31 \%$.
\end{abstract}

\section{Kata kunci: halogen, kesulitan, konsep}

\section{Pendahuluan}

Kimia sering terkesan lebih sulit. Salah satu faktor penyebab mempelajari kimia terkesan sulit adalah kimia memiliki perbendaharaan kata yang khusus, dimana mempelajari kimia seperti mempelajari bahasa yang baru serta beberapa konsepnya bersifat abstrak (Chang, 2005). Kesulitan yang dihadapi oleh mahasiswa merupakan salah satu faktor penyebab rendahnya mutu pendidikan. Usaha perbaikan mutu pendidikan dilakukan oleh pihak pemerintah yang bertujuan untuk meningkatkan kemampuan guru dan memperkenalkan beberapa metode pembelajaran. Usaha perbaikan jarang sekali bertumpu pada kesulitan yang dialami oleh mahasiswa. Masril \& Asma dalam Suwarto (2013:5) menyatakan untuk melengkapi usaha perbaikan yang bertumpu pada kesulitan mahasiswa maka terlebih dahulu harus diketahui kesulitan apa yang dialami oleh mahasiswa.

Menurut Webster dalam Sobur (2006) wacana merupakan terjemahan dari bahasa Inggris discourse yaitu komunikasi pikiran dengan kata-kata; ekspresi ideide atau gagasan-gagasan; konversasi atau percakapan juga dapat berupa komunikasi secara umum, terutama sebagai suatu subjek studi atau pokok telaah.

Peneliti tertarik untuk menggunakan wacana sebagai instrumen penelitian karena belum ada penelitian skiripsi tentang kesulitan yang menggunakan instrumen wacana, hal ini cocok dengan metode pembelajaran K13 yaitu tematik terintegrasi. Rumusan masalah penelitian ini adalah bagaimana menjelaskan kesulitan yang dialami mahasiswa Program Studi Pendidikan Kimia Universitas 
Palangka Raya tahun akademik 2018/2019 dalam memahami konsep kimia unsur golongan VII A (halogen). Penelitian ini bertujuan untuk mendeskripsikan kesulitan dalam memahami konsep kimia unsur golongan VII A (halogen) pada mahasiswa Program Studi Pendidikan Kimia Universitas Palangka Raya. Penelitian ini diharapkan dapat memberikan sumbangan yang berguna untuk mengembangkan keilmuan dalam rangka pengembangan pendidikan dan pengajaran.

\section{Metode Penelitian}

Penelitian ini merupakan penelitian dengan metode deskriptif, yaitu dengan mendeskripsikan suatu gejala peristiwa atau kejadian yang terjadi pada masa sekarang (Sudjana, 2005). Penelitian ini dilaksanakan di Program Studi Pendidikan Kimia Universitas Palangka Raya. Penelitian dilaksanakan pada semester ganjil tahun akademik 2018/2019. Subjek dalam penelitian adalah mahasiswa Program Studi Pendidikan Kimia semester I, III, dan V.

Pengumpulan data dalam penelitian ini menggunakan wacana dan wawancara. Cara mengumpulkan data menggunakan wacana atau Wacana Kimia Unsur Halogen (WKUH) ialah sebagai berikut:

1. Pemberitahuan pelaksanaan pengambilan data kepada subjek penelitian dilakukan dua hari sebelum pemberian wacana.

2. Instrumen WKUH diberikan kepada mahasiswa yang menjadi subjek penelitian pada saat waktu yang telah disediakan.

3. Pengerjaan wacana diawasi oleh tiga orang pengamat agar mahasiswa mengerjakan instrumen WKUH dengan sungguh-sungguh.

Wawancara dilakukan dengan cara sebagai berikut:

1. Wawancara dilakukan dengan alat dokumentasi.

2. Lembar hasil jawaban mahasiswa yang terpilih untuk diwawancarai diberikan kepada mahasiswa tersebut.

3. Mahasiswa diminta untuk mencermati soal dan hasil jawaban miliknya.

4. Mahasiswa diminta menjelaskan hasil jawabannya.

5. Pertanyaan yang diajukan selama wawancara dikembangkan mengikuti respon mahasiswa.

Data kesulitan mahasiswa dalam memahami konsep kimia unsur halogen ditelusuri dengan cara memberikan soal Wacana Kimia Unsur Halogen (WKUH) sebanyak 84 butir soal. Data ragam jawaban siswa terhadap (WKUH) dianalisis dengan tahap-tahap sebagai berikut:

1. Memberikan skor untuk setiap butir soal pada hasil pekerjaan siswa. Pemberian skor, setiap butir soal disesuaikan dengan rubrik penilaian. Selanjutnya menentukan persentase skor jawaban benar siswa dengan rumus berikut:

Keterangan :

$$
N P=\frac{R}{S M} \times 100
$$

$\mathrm{NP}=$ nilai persen yang dicari atau diharapkan

$\mathrm{R}=$ skor mentah yang diperoleh siswa

$\mathrm{SM}=$ skor maksimum

$100=$ bilangan tetap 
2. Menggolongkan mahasiswa yang berhasil memperoleh skor lebih besar atau sama dengan Ketuntasan Belajar Minimal (KBM). KBM yang digunakan peneliti adalah 75 .

3. Mengelompokkan jawaban salah mahasiswa berdasarkan ragam jawaban mahasiswa. Penelitian kesulitan ini memuat data rerata skor salah mahasiswa dari keenam topik. Data rerata skor salah per topik digunakan untuk mengetahui tingkat kemampuan mahasiswa yang dapat ditelusuri pada grafik. Semakin tinggi nilai rerata skor salah mahasiswa maka tingkat kemampuan mahasiswa pada topik itu semakin rendah.

4. Mendeskripsikan ragam jawaban mahasiswa untuk menjelaskan kesulitan yang dialami oleh mahasiswa dalam pemahaman konsep kimia unsur golongan VII A (halogen).

5. Setelah diperoleh hasil analisis data, melakukan wawancara untuk memperkuat deskripsi tentang kesulitan mahasiswa. Data hasil penelitian yang terkumpul melalui lembar jawaban mahasiswa dari setiap semester menunjukkan hasil jawaban mahasiswa yang beragam dengan tingkat kesulitan yang berbeda-beda.

\section{Hasil Penelitian Dan Pembahasan}

Wacana kimia unsur terdiri dari lima puluh butir soal dengan masingmasing lembar jawaban diberikan skor. Hasil tes pemahaman konsep kimia unsur halogen dinyatakan tuntas apabila mahasiswa memperoleh skor $\geq 75 \%$ sesuai dengan nilai KBM yang telah ditentukan yaitu 75. Persentase mahasiswa yang dinyatakan tuntas sebesar $13,51 \%$ atau sebanyak 15 mahasiswa dari 111 mahasiswa. Skor total jika menjawab butir soal benar pada topik kereaktifan adalah 8, pada topik keperiodikan adalah 10, pada topik kelarutan adalah 4, pada topik oksidator-reduktor adalah 5, pada topik asam-basa adalah 6 , dan pada topik manfaat, cara, dan dampak adalah 17. Sehingga skor maksimum untuk seluruh butir soal adalah 50, dengan skor ideal sebesar 75. Mahasiswa dinyatakan mengalami kesulitan jika skor rerata dibawah skor ideal. Sebanyak 3 orang mahasiswa memperoleh skor tertinggi dan 11 orang mahasiswa memperoleh skor terendah.

Persentase kesulitan mahasiswa setiap semester menunjukkan bahwa dominan kesulitan mahasiswa terbesar terdapat pada topik asam-basa, oksidatorreduktor, dan kelarutan. Dominan kesulitan mahasiswa terkecil terdapat pada topik kereaktifan, manfaat, cara, dan dampak, serta topik keperiodikan. Hasil uji coba instrumen menunjukkan bahwa tingkat kesukaran butir soal butir-butir soal untuk topik kereaktifan termasuk kriteria soal mudah, topik keperiodikan, kelarutan, dan oksidator-reduktor termasuk kriteria sedang, topik asam-basa serta topik manfaat, cara, dan dampak termasuk soal sukar.

Hasil jawaban mahasiswa semester I, III, dan V pada topik kereaktifan, keperiodikan, kelarutan, oksidator-reduktor, asam-basa, serta manfaat, cara, dan dampak menunjukkan perbedaan tingkat pemahaman yang berbeda-beda. Pada topik kereaktifan menunjukkan mahasiswa yang salah dalam mengidentifikasi kereaktifan unsur golongan VII A (halogen) yang terdapat di alam yaitu sebanyak 69 orang. Topik keperiodikan menunjukkan mahasiswa yang salah dalam mengidentifikasi sifat keperiodikan unsur golongan VII A (halogen) yang terdapat di alam yaitu sebanyak 43 orang. Indikator kelarutan menunjukkan mahasiswa 
yang salah dalam mengidentifikasi sifat kelarutan unsur golongan VII A (halogen) yang terdapat di alam yaitu sebanyak 58 orang. Topik oksidator-reduktor menunjukkan mahasiswa yang salah dalam mengidentifikasi sifat oksidator dan reduktor unsur golongan VII A (halogen) yang terdapat di alam yaitu sebanyak 54 orang. Topik asam-basa menunjukkan mahasiswa yang salah dalam mengidentifikasi sifat asam basa unsur golongan VII A (halogen) yang terdapat di alam yaitu sebanyak 61 orang. Topik manfaat, cara, dan dampak menunjukkan mahasiswa yang salah dalam mengidentifikasi cara pembuatan, manfaat, dan dampak penggunaan unsur golongan VII A (halogen) dalam kehidupan seharihari yaitu sebanyak 47 orang. Perbandingan rerata skor salah mahasiswa berdasarkan topik soal disajikan pada grafik 1 .

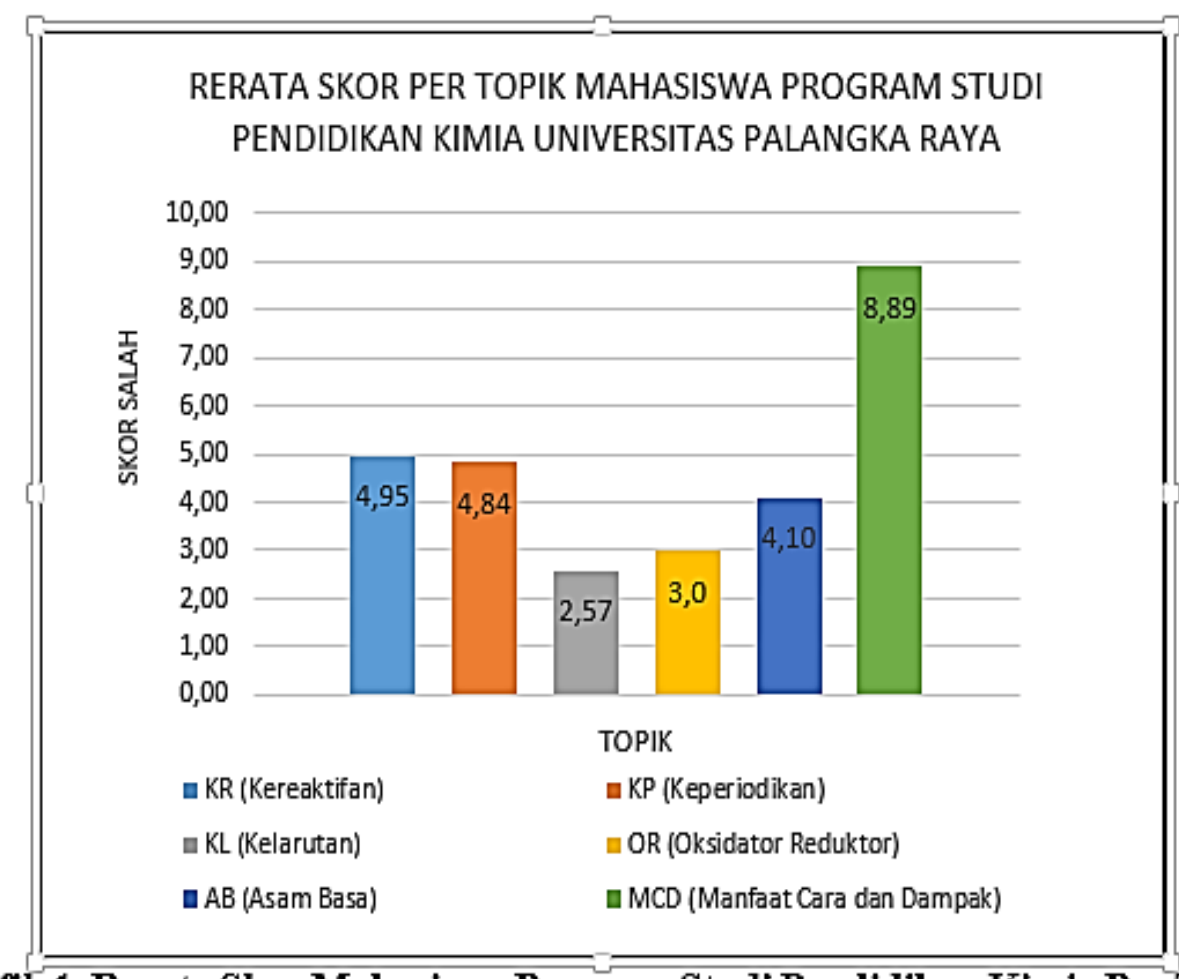

\section{Grafik 1. Rerata Skor Mahasiswa Program Studi Pendidikan Kimia Per Topik}

Pola jawaban mahasiswa merupakan gambaran letak kesulitan yang dialami mahasiswa pada setiap butir soal. Pola ini digunakan untuk mengungkap kesulitan mahasiswa dalam memahami konsep kimia unsur halogen. Pola jawaban mahasiswa melalui WKUH merupakan kesulitan yang dialami oleh mahasiswa. Penelitian ini bertujuan untuk mendeskripsikan kesulitan mahasiswa berdasarkan pola jawaban salah dominan mahasiswa dalam menyelesaikan WKUH yang meliputi enam topik, yaitu:

1. Mengidentifikasi kereaktifan unsur golongan VII A (halogen) yang terdapat di alam.

2. Mengidentifikasi sifat keperiodikan unsur golongan VII A (halogen) yang terdapat di alam.

3. Mengidentifikasi sifat kelarutan unsur golongan VII A (halogen) yang terdapat di alam. 
4. Mengidentifikasi sifat oksidator dan reduktor unsur golongan VII A (halogen) yang terdapat di alam.

5. Mengidentifikasi sifat asam basa unsur golongan VII A (halogen) yang terdapat di alam.

6. Mendeskripsikan cara pembuatan, manfaat, dan dampak penggunaan unsur golongan VII A (halogen) dalam kehidupan sehari-hari.

Kesulitan mahasiswa dalam mengidentifikasi kereaktifan unsur golongan VII A (halogen) yang terdapat di alam ditelusuri menggunakan butir soal 2 . Kesulitan mahasiswa dalam mengidentifikasi sifat keperiodikan unsur golongan VII A (halogen) yang terdapat di alam ditelusuri menggunakan butir soal 15 . Kesulitan mahasiswa dalam mengidentifikasi sifat kelarutan unsur golongan VII A (halogen) yang terdapat di alam ditelusuri menggunakan butir soal 25 . Kesulitan mahasiswa dalam mengidentifikasi sifat oksidator dan reduktor unsur golongan VII A (halogen) yang terdapat di alam ditelusuri menggunakan butir soal 32. Kesulitan mahasiswa dalam mengidentifikasi sifat asam basa unsur golongan VII A (halogen) yang terdapat di alam ditelusuri menggunakan butir soal 39. Kesulitan mahasiswa dalam mendeskripsikan cara pembuatan, manfaat, dan dampak penggunaan unsur golongan VII A (halogen) dalam kehidupan sehari-hari ditelusuri menggunakan butir soal 42 dan 19.

Mahasiswa masuk kategori sulit apabila skor rerata lebih kecil atau sama dengan skor ideal per indikator. Skor rerata mahasiswa semester I, III, V pada setiap topik disajikan pada Tabel 1 .

Tabel 1 Skor Rerata Mahasiswa Semester I, II, dan V Pada Setiap Topik

\begin{tabular}{lccccc}
\hline Topik & $\begin{array}{c}\text { Skor } \\
\text { Maksimal }\end{array}$ & $\begin{array}{c}\text { Skor } \\
\text { Ideal }\end{array}$ & & \multicolumn{3}{c}{ Skor Rerata Setiap Semester } \\
\cline { 4 - 6 } & & & & & \multicolumn{2}{c}{$\begin{array}{l}\text { Semester } \\
\text { III }\end{array}$} & Semester V \\
\hline Kereaktifan & 8 & 6 & 2,2 & 3,07 & 3,60 \\
\hline Keperiodikan & 10 & 7,5 & 3,39 & 5,39 & 6,12 \\
\hline Kelarutan & 4 & 3 & 1,29 & 1,37 & 1,60 \\
\hline $\begin{array}{l}\text { Oksidator- } \\
\text { Reduktor }\end{array}$ & 5 & 3,75 & 1,21 & 2,22 & 2,31 \\
\hline Asam-Basa & 6 & 4,5 & 1,39 & 1,61 & 2,52 \\
\hline $\begin{array}{l}\text { Manfaat, } \\
\begin{array}{l}\text { Cara, } \\
\text { Dampak }\end{array}\end{array}$ & 17 & 12,75 & 6,14 & 8,49 & 9,05 \\
\hline
\end{tabular}

Pada Tabel 1, enam topik yang dijadikan bahan penelitian mempunyai skor rerata lebih rendah daripada skor ideal yang artinya mahasiswa mengalami kesulitan tentang mengidentifikasi kereaktifan unsur golongan VII A (halogen) yang terdapat di alam, mengidentifikasi sifat keperiodikan unsur golongan VII A (halogen) yang terdapat di alam, mengidentifikasi sifat kelarutan unsur golongan VII A (halogen) yang terdapat di alam, mengidentifikasi sifat oksidator dan reduktor unsur golongan VII A (halogen) yang terdapat di alam, mengidentifikasi sifat asam basa unsur golongan VII A (halogen) yang terdapat di alam, mendeskripsikan cara pembuatan, manfaat, dan dampak penggunaan unsur golongan VII A (halogen) dalam kehidupan sehari-hari. 
Mengidentifikasi Kereaktifan Unsur Golongan VII A (Halogen) yang Terdapat di Alam. Pada tahun 1887 S. Arrhenius mengajukan bahwa apabila suatu elektrolit melarut, sebagian elektrolit ini terurai menjadi partikel positif dan partikel negatif yang disebut ion. Teori ini berhasil menjelaskan beberapa hal misalnya elektrolisis dan hantaran elektrolit. Menurut teori ini, asam dalam larutan air menghasilkan ion hidrogen, dan basa dalam larutan air menghasilkan ion hidroksida yang menetralkan asam sesuai dengan reaksi,

$\mathrm{H}++\mathrm{OH}-\rightarrow \mathrm{H} 2 \mathrm{O}$

Menurut Bronsted-Lowry asam adalah zat yang dapat memberikan proton (donor proton).

Asam $\rightleftharpoons$ Basa $+\mathrm{H}+$

Menurut Lewis asam adalah setiap spesi yang mengandung atom yang dapat menerima pasangan elektron atau akseptor (Achmad, 2001: 97-102).

Hasil penelitian menunjukkan sebagian besar (45\%) mahasiswa mengalami kesulitan dalam mengidentifikasi sifat kereaktifan unsur golongan VII A (halogen) yang terdapat di alam. Pola kesulitan mahasiswa terhadap konsep mengidentifikasi sifat kereaktifan unsur golongan VII A (halogen) yang terdapat di alam sebanyak 4 pola, dengan pola yang dominan yaitu penulisan asam pada soal mengidentifikasi bahwa halogen bersifat asam.

Mengidentifikasi Sifat Keperiodikan Unsur Golongan VII A (Halogen) yang Terdapat di Alam. Halogen memiliki sifat tertentu dan berubah dengan teratur dari satu unsur ke unsur yang berikutnya. Kenaikan titik didih dengan bertambahnya nomor atom, dijelaskan dengan fakta bahwa molekul-molekul yang lebih besar, mempunyai gaya tarik menarik Van Der Walls yang lebih besar daripada yang dimiliki molekul-molekul yang lebih kecil (Kenan, 1984:228).

Hasil penelitian menunjukkan sebagian besar (52\%) siswa mengalami kesulitan dalam mengidentifikasi sifat keperiodikan unsur golongan VII A (halogen) yang terdapat di alam. Pola kesulitan mahasiswa terhadap konsep mengidentifikasi sifat keperiodikan unsur golongan VII A (halogen) yang terdapat di alam sebanyak 5 pola, dengan pola yang dominan yaitu penulisan titik didih pada soal mengidentifikasi bahwa halogen memiliki titik didih yang paling tinggi dari semua golongan.

Mengidentifikasi Sifat Kelarutan Unsur Golongan VII A (Halogen) yang Terdapat di Alam. Beberapa sifat fisika dari halogen yaitu kenaikan titik didih dan titik lelehnya yang disebabkan dengan bertambahnya nomor atom (Kenan, 1984:228). Kelarutan dalam air berkurang dari flourin ke iodin. Halogen lebih mudah larut dalam pelarut nonpolar. (Michael Purba, 2004).

Hasil penelitian menunjukkan sebagian besar (36\%) mahasiswa mengalami kesulitan dalam mengidentifikasi sifat kelarutan unsur golongan VII A (halogen) yang terdapat di alam. Pola kesulitan mahasiswa terhadap konsep mengidentifikasi sifat kelarutan unsur golongan VII A (halogen) yang terdapat di alam sebanyak 7 pola, dengan pola yang dominan yaitu penulisan nomor atom pada soal mengidentifikasi kelarutan halogen dalam air pada satu golongan semakin kecil karena bertambahnya jari-jari atom.

Halogen lebih mudah larut dalam pelarut nonpolar, cara menentukan kepolaran senyawa yaitu berdasarkan elektron valensi. Elektron valensi diperoleh dari konfigurasi elektron berdasarkan nomor atom. 
Mengidentifikasi Sifat Oksidator dan Reduktor Unsur Golongan VII A (Halogen) yang Terdapat di Alam. Halogen merupakan pengoksidasi kuat. Daya pengoksidasi halogen menurun dari atas ke bawah, yaitu dari fluorin ke iodin. Sebaliknya, daya redukasi ion halida $\left(\mathrm{X}^{-}\right)$bertambah dari atas ke bawah. Jadi, $\mathrm{I}^{-}$ merupakan reduktor terkuat, sedangkan $\mathrm{F}^{-}$merupakan reduktor terlemah. Daya oksidasi halogen atau daya pereduksi ion halida dicerminkan oleh potensial eklektrodenya.

Makin positif harga potensial elektrode, maka spesi itu makin mudah mengalami reduksi, berarti merupakan pengoksidasi kuat (Purba, 2004). Potensial reduksi F2 paling besar sehingga akan mudah mengalami reduksi dan disebut oksidator terkuat.

Hasil penelitian menunjukkan sebagian besar (40\%) mahasiswa mengalami kesulitan dalam mengidentifikasi sifat reduktor-oksidator unsur golongan VII A (halogen) yang terdapat di alam. Pola kesulitan mahasiswa terhadap konsep mengidentifikasi sifat reduksi-oksidasi unsur golongan VII A (halogen) yang terdapat di alam sebanyak 5 pola, dengan pola yang dominan yaitu penulisan reduksi pada soal mengidentifikasi mudah mengalami reduksi sama dengan mudah melepas elektron.

Mengidentifikasi Sifat Asam Basa Unsur Golongan VII A (Halogen) yang Terdapat di Alam. Reaksi halogen dengan basa encer dingin menghasil halida (X) dan hipohalida (XO-), sedang reaksi halogen dengan basa pekat panas menghasilkan halida (X-) dan halat (XO3-). Hidrogen halida dapat diperoleh melalui reaksi antara logam halida dengan asam sulfat pekat. Hidrogen Bromida tidak dapat dihasilkan melalui reaksi antara logam halida dengan asam sulfat pekat.

Brom digunakan sebagai bahan dasar pembuatan senyawa Etilena dibromida $\left(\mathrm{BrCH}_{2} \mathrm{CH}_{2} \mathrm{Br}\right)$, suatu insektisida. Senyawa ini sangat karsinogenik. Brom juga dapat bereaksi dengan perak menghasilkan senyawa Perak Bromida $(\mathrm{AgBr})$ yang digunakan dalam lembaran film fotografi.

Hasil penelitian menunjukkan sebagian besar (32\%) mahasiswa mengalami kesulitan dalam mengidentifikasi sifat asam-basa unsur golongan VII A (halogen) yang terdapat di alam. Pola kesulitan mahasiswa terhadap konsep mengidentifikasi sifat asam-basa unsur golongan VII A (halogen) yang terdapat di alam sebanyak 8 pola, dengan pola yang dominan yaitu penulisan etilena dibromida pada soal mengidentifikasi hidrogen bromida dan etilena dibromida tidak dapat dihasilkan melalui reaksi halogen dengan basa cair maupun pekat.

Mendeskripsikan Cara Pembuatan, Manfaat, dan Dampak Penggunaan Unsur Golongan VII A (Halogen) dalam Kehidupan Sehari-hari. Halida adalah senyawa biner dimana salah satu bagiannya adalah salah satu halogen dan bagian lainnya adalah elemen lainnya atau radikal yang mempunyai tingkat keelektronegatifan lebih kecil daripada atom halogen, untuk membentuk suatu senyawa halogen fluoride, klorida, bromida, iodida atau astatain. Kebanyakan garam merupakan halida. Semua logam pada golongan 1 akan membentuk halida yang berbentuk padatan putih dalam suhu ruangan. Ion halida adalah suatu atom hidrogen yang mengikat muatan negatif. Anion halida cntohnya yaitu fluorida (F), klorida (Cl-), bromida (Br-), Iodida (I-) serta unsur halogen lainnya yaitu astatin (At). Semua ion ini terdapat pada garam halida ion (Keenan, 1984). Senyawa 
bromida ditemukan di air laut (ion $\mathrm{Br}$-), diperoleh dari air laut melalui oksidasi ion bromida dalam larutan oleh klorin.

Hasil penelitian menunjukkan sebagian besar (48\%) mahasiswa mengalami kesulitan dalam mendeskripsikan cara pembuatan, manfaat, dan bahaya penggunaan unsur halogen dalam kehidupan sehari-hari unsur golongan VII A (Halogen) yang terdapat di alam. Pola kesulitan mahasiswa terhadap konsep mendeskripsikan cara pembuatan, manfaat, dan bahaya penggunaan unsur halogen dalam kehidupan sehari-hari yang terdapat di alam sebanyak 8 pola, dengan pola yang dominan yaitu penulisan ion dibromida pada soal mendeskripsikan senyawa $\mathrm{BrCH}_{2} \mathrm{CH}_{2} \mathrm{Br}$ merupakan suatu ion bromida.

\section{Kesimpulan}

Kesimpulan yang diperoleh dari hasil penelitian, yaitu:

1. Kesulitan mahasiswa dalam memahami konsep kimia unsur halogen pada penyelesaian soal tentang mengidentifikasi sifat kereaktifan unsur golongan VII A (halogen) yang terdapat di alam dengan persentase sebesar 61,94\%.

2. Kesulitan mahasiswa dalam memahami konsep kimia unsur halogen pada penyelesaian soal tentang mengidentifikasi sifat keperiodikan unsur golongan VII A (halogen) yang terdapat di alam dengan persentase $48,38 \%$.

3. Kesulitan mahasiswa dalam memahami konsep kimia unsur halogen pada penyelesaian soal tentang mengidentifikasi sifat kelarutan unsur golongan VII A (halogen) yang terdapat di alam dengan persentase $64,19 \%$.

4. Kesulitan mahasiswa dalam memahami konsep kimia unsur halogen pada penyelesaian soal tentang mengidentifikasi sifat oksidator dan reduktor unsur golongan VII A (halogen) yang terdapat di alam dengan persentase $60 \%$.

5. Kesulitan mahasiswa dalam memahami konsep kimia unsur halogen pada penyelesaian soal tentang mengidentifikasi sifat asam basa unsur golongan VII A (halogen) yang terdapat di alam dengan persentase 68,32\%.

6. Kesulitan mahasiswa dalam memahami konsep kimia unsur halogen pada penyelesaian soal tentang mendeskripsikan cara pembuatan, manfaat, dan bahaya unsur golongan VII A (halogen) dalam kehidupan sehari-hari dengan persentase $52,31 \%$.

\section{Daftar Rujukan}

Carin, A. A. \& Sund, R.B. (1989). Chemistry A Modern Course. Colombus: Merrill Publishing Company.

Chang, Raymond. 2005. Kimia Dasar, Konsep-konsep Inti Edisi Ketiga, Jilid 1. Jakarta: Erlangga.

Cotton, F. A, dan Wilkinson. G. 1984. Kimia Anorganik Dasar. Jakarta: UI Press.

Dahar, Ratna Wilis. 2011. Teori-Teori Belajar dan Pembelajaran. Jakarta: Erlangga.

Harjasujana, A.S. \& Mulyati, Y. (1997). "Membaca 2", Modul Universitas

Terbuka. Jakarta: Depdikbud.

Keenan, Charles W.1984.Kimia untuk Universitas. Jakarta: Erlangga.

Keenan, Charles W.1986.Kimia Dasar Prinsip dan Terapan Modern Edisi Keempat. Jakarta: Erlangga.

Sudjana, Nana. 2005. Dasar-dasar Proses Belajar Mengajar. Bandung: Sinar Baru Algensindo. 
Sudjana, Nana. 2006. Penilaian Hasil Proses Belajar Mengajar. Bandung: Rosdakarya.

Keenan, W. Charles. 1986. Ilmu Kimia Untuk Universitas Edisi VI. Jakarta : Erlangga.

Purba, Michael. 2006. Kimia 3 Untuk SMA Kelas XII. Jakarta: Erlangga.

Sobur, Alex. 2006. Semiotika Komunikasi. Bandung: Rosdakarya.

Sukmadinata, Nana S. 2012. Metode Penelitian Pendidikan. Bandung: PT Remaja Rosdakarya.

Sunarya, Yayan. 2012. Kimia Dasar 2. Bandung: Yrama Widya.

Suwarto. 2013. Pengembangan Tes Diagnostik dalam Pembelajaran. Yogyakarta: Pustaka Pelajar.

Tarigan, H. G. 1987. Pengajaran Wacana. Bandung: Angkasa. 